\title{
Library Instruction in an Age of Misinformation
}

\author{
Sarah E. Morris
}

Emory University

\begin{abstract}
Library instruction has evolved and responded to changes in our media ecosystem for decades. And the current rise of, and interest in, misinformation presents a number of challenges and opportunities for librarians engaging in instruction work. Our current age of misinformation is somewhat unprecedented in terms of scale, and library instruction has an opportunity to innovate and grow in order to meet these new challenges. Librarians can meet the challenges posed by misinformation and our media ecosystem head-on and turn them into opportunities to develop new instruction programming that takes both a broader and a more contextualized approach to information literacy instruction. By situating the evolution of library instruction into a broader narrative of a rapidly changing media landscape, we can consider how librarians can utilize innovative approaches to library instruction to empower and equip students with the multiple literacies and fluencies that they need to succeed not just in their current academic endeavors but also in their role as information consumers and producers in an increasingly complicated and challenging media ecosystem.
\end{abstract}

Keywords: misinformation, library instruction, information literacy, media literacy

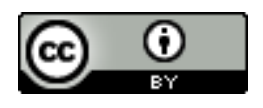

This is an Open Access article distributed under the terms of the Creative Commons Attribution 4.0 International License (http://creativecommons.org/licenses/by/4.0), which permits unrestricted use, distribution, and reproduction in any medium, provided the original work is properly cited.

Journal of New Librarianship, 4(2019) pp. 560-567 10.21173/newlibs/8/12 


\section{Introduction}

Libraries and librarians have always been at the forefront of helping people navigate information economies and media ecosystems. And these ecosystems are growing increasingly complex, which presents a number of challenges and opportunities for librarians. The complexity of these media ecosystem stems, in part, from the fact that for every new development in communication technologies, from the printing press to radio to the Internet chat room to the meme, there is a concomitant development in misinformation. If people can find a way to communicate with a new technology or a new form of media, then someone, somewhere, will figure out how to spread information of varying, and even dubious, quality using said new media.

The history of library instruction is part of the history of the development of modern media ecosystems, our efforts to manage information overload with new technologies, and the challenges these systems and technologies pose. Aside from equipping people to navigate information with things like search skills, librarians also focus a great deal of their instruction efforts on empowering people with the skills they need to think critically about information. And it is this latter focus that positions librarians to launch innovative instruction programming that can equip students to handle the immense challenges posed by our media ecosystems, and the accompanying challenges of misinformation. In the midst of evolving media ecosystems, library instruction itself has an opportunity to evolve, to take innovative and interdisciplinary approaches to information literacy instruction, and to draw on a rich legacy even as we chart new paths.

\section{Evolving Media and Evolving Library Instruction}

According to Salony (1995), the modern emergence of library instruction happened in the 1960s and 1970s, partly in response to the rise of new computer technologies, which were rapidly changing 
the information landscape. Information literacy itself emerged as a term in 1972 (Badke, 2010) and was, at the time, focused on concerns with the changing information economy and the need to equip people with skills to succeed in this new economy. But I find it fascinating that this growth in library instruction came along not just with an explosion of new technology and the accompanying concerns about the labor market but also in an era that proved a critical inflection point for the modern media ecosystem, where society was grappling with issues of trust and credibility in the wake of Vietnam and Watergate.

There can be something of a dissonance within library instruction, where it is as much a part of a sweeping narrative of modern media ecosystems and technological change as it is a key component of a class research project. As librarians, we can and do operate on both a macro and a micro level with our work. We inhabit a world of complex media ecosystems, evolving information economies, and changing technologies, as well as the immediate realities of things like the needs of a student research project. And in the midst of these complex and evolving systems are individual people with a whole host of beliefs and biases. Both we and our students bring beliefs and viewpoints and past experiences and ideas, some of which are evolving, some of which are strongly rooted, and some of which might be influenced by less-than-credible information.

Librarians exist in an epicenter of changing technology and media that pose deep and profound questions around civic engagement, digital citizenship, power structures, human psychology, privacy, and a whole array of topics related to our current age of misinformation. And librarians also exist in an epicenter of personal beliefs and views that are formed and influenced by, for good or ill, our complicated technology and media ecosystems. What does and can library instruction 
look like amidst these challenges, and how can librarians navigate complicated issues surrounding media and technology ecosystems and our own individual places within these ecosystems?

\section{Misinformation and Information Literacy}

The new age of misinformation we now inhabit is in many respects unprecedented. We are grappling with a collision of new technologies, and new media ecosystems and economies, that allow misinformation to spread farther and faster than ever before. We are confronting a wide range of misinformation types, from disinformation campaigns sponsored by state actors to viral rumors to a misreading of a satirical Onion article to "deep fake" videos. And we are dealing with things like filter bubbles, the 24-hour news cycle, influencers, clickbait, troll farms, and "container collapse," an idea that emerges from research conducted by OCLC, Rutgers, and the University of Florida which suggests that the Internet strips sources of valuable identifying information, making evaluating content difficult (Connaway, 2018). Students and patrons are coming to us with a wide range of experiences and comfort levels and views shaped by misinformation and new technologies and media. For librarians engaged in instruction, we are increasingly grappling with highly complex and evolving media environments, striving to empower students and patrons with the skills they need to navigate those environments, and managing what can sometimes be difficult conversations around personal and political beliefs and how those intersect with issues surrounding misinformation.

Misinformation is a complicated topic that has given rise to a number of associated terms, from Wardle and Derakhshan's (2017) evocative take on “information disorder," which captures a wide ranging malaise with regards to how we encounter misinformation online to ideas of information fluency and web literacy from Mike Caulfield (2017), who posits an information literacy more suited for the Internet age. And misinformation introduces a host of things that an information literate person 
could benefit from understanding, from the psychology behind the appeal of conspiracy theories, to the production mechanisms of modern media, to how algorithms shape our online experiences.

Being information literate was never just about being able to find information, but today information literacy, and library instruction, need to involve a whole range of other literacies and skills, from digital literacy to data literacy to media literacy to web literacy as well as the incredibly valuable ideas behind critical information literacy or an "attempt to render visible the complex workings of information so that we may identify and act upon the power structures that shape our lives" (Tewell, 2016). Research from David Buckingham (2006) emphasizes this notion of the importance of multiple literacies, with literacy as more than just competencies; rather, these multiple literacies can take a broader and deeper form and focus on the cultural implications of new media technologies.

The role of a librarian is critical and our work to empower people to grapple with the challenges posed by misinformation, new technologies, and our complex media ecosystem requires new approaches and innovation. We have both an opportunity and a need to situate and contextualize our instruction, to make it relevant, and to ensure students are equipped to excel in a world beset by challenges from misinformation.

\section{Tackling Misinformation with Library Instruction}

Library instruction inhabits a space between the immediate needs of a class research assignment and the seismic shifts in things like communication technologies. Librarians can face a challenge where the classes they work with, and the assignments they support, might be operating on one plane of literacies, while the world students engage with online, and outside of the classroom, can touch upon a whole other set of topics, trends, and literacies. 
More than ever before, library instruction and librarians can benefit from emphasizing the applicability and transferability of certain skills and concepts, to ensure that students are empowered to both complete a research paper and fact-check a pernicious meme. And librarians are uniquely situated to bridge those gaps. A study from researchers at Stanford on fact-checking abilities in certain groups found that journalists were much better fact-checkers, due to their ability to read laterally, or go outside the text to confirm information, than PhD students and suggests that librarians would score as high as journalists in further studies (Wineberg and McGrew 2017). In our current era of misinformation, librarians have the opportunity to embrace expertise in a number of critical skill areas, to communicate that expertise to partners and stakeholders, and to leverage our instruction to deal with a number of complex challenges.

This communication aspect is key to the work we do. Our students and patrons might have quite variable experiences with and reactions to misinformation and surrounding topics. Some people might treat it as a joke, some people might just feel demoralized about challenges surrounding misinformation, some people might hold views influenced by non-credible information. Acknowledging the often intensely personal and emotional aspects of consuming and producing media, and of forming beliefs, is, I feel, increasingly vital in library instruction scenarios. Likewise, engaging with ideas from places like the ACRL Framework for Information Literacy and critical information literacy around issues of authority and the socially constructed nature of knowledge is also increasingly vital. Issues surrounding misinformation and modern media and technology ecosystems are incredibly complex and librarians, aside from equipping people with skills, can play a role in providing spaces for our students and patrons to think critically and reflect on these issues and how these issues impact their personal views and identities. In her thought-provoking article "I am not 
your Fake News Savior," Carrie Wade (2018) argues for ensuring that theory, critical thinking, and reflection are included in education around topics like misinformation, while also noting that librarians aren't some sort of magical solution to our society's misinformation woes. There is really no easy solution to the challenges posed by misinformation, but I do believe that librarians can make important contributions to the conversation and to educational efforts around media literacy.

Aside from emphasizing the transferrable nature library instruction, which can help with both the immediate needs of an assignment and larger concerns posed by misinformation, librarians can consider other ways to respond to the challenges of our current age of misinformation. Librarians can leverage their expertise to establish vital and collaborative partnerships to support students in acquiring critical information literacy skills. We can work with faculty to develop relevant and engaging research assignments, such as ones that incorporate new media technologies, team up with local journalists to host fact-checking workshops, and listen to, learn from, and respond to the needs and interests of our students. I find the work of Nina Simon (2016) particularly valuable in this area, where she posits an idea of "community-first program design" which outlines ways to engage in dialogue, create spaces for a diverse array of voices, prioritize the power of listening, and collaboratively develop programs that are driven by a given community and their ideas, needs, and interests.

Misinformation is a daunting and complicated, albeit compelling, topic for many people, our patrons included. We have an opportunity to connect with and work with our patrons to help them grapple with a number of challenging and difficult issues associated with misinformation, whether that involves helping people develop the skills they need to feel more confident online or helping people delve into thorny questions around the power structures that govern our media ecosystems. 
Communicating these goals to our patrons can help us open doors with regards to new instruction opportunities.

Finally, librarians can consider new, interdisciplinary approaches to our instruction that help us, and our patrons, tackle challenges posed by our current age of misinformation. From exploring other literacies to activities that help students gain a fluency and a comfort with navigating different online environments to lessons that help students gain a more nuanced understanding of the media ecosystems we all inhabit, library instruction can build upon its long and rich legacy and consider new approaches in response to new challenges raised by misinformation.

By focusing on transferrable skills, critical approaches to information literacy that consider the deeper issues and challenges posed by our current media ecosystem and by misinformation, interdisciplinary partnerships, and broader approaches to library instruction that can incorporate other literacies, such as web or data literacy, librarians can play a powerful role in equipping students to succeed not just in their current academic environs but in their future endeavors and, more broadly, as consumers and producers of media in the $21^{\text {st }}$ century.

\section{References}

Badke, W. (2010). Foundations of information literacy: Learning from Paul Zurkowski. Online, 34(1), 48-

50.

Buckingham, D. (2006). Defining digital literacy-What do young people need to know about digital media? Nordic Journal of Digital Literacy, 1(4), 263-277.

Caulfield, M. (2017). Web literacy for student fact-checkers. Michael Arthur Caulfield. Retrieved from https://webliteracy.pressbooks.com/ 
Connaway, L.S. (2018). What is "container collapse" and why should librarians and teachers care? OCLC Next. Retrieved from http://www.oclc.org/blog/main/what-is-container-collapse-and-whyshould-librarians-and-teachers-care/

Salony, M. F. (1995). The history of bibliographic instruction: Changing trends from books to the electronic world. The Reference Librarian, 24(51-52), 31-51.

Simon, N. (2016). The art of relevance. Museum 2.0.

Tewell, E. (2016). Putting critical information literacy into context: How and why librarians adopt critical practices in their teaching. In the Library with the Lead Pipe. Retrieved from http://www.inthelibrarywiththeleadpipe.org/2016/putting-critical-information-literacy-intocontext-how-and-why-librarians-adopt-critical-practices-in-their-teaching/

Wade, C. (2018). "I am not your fake news savior." Library Barbarian. Retrieved from https://seadoubleyew.com/150/i-am-not-your-fake-news-savior/

Wardle, C., \& Derakhshan, H. (2017). Information Disorder: Toward an interdisciplinary framework for research and policy making. Council of Europe Report, 27.Retrieved from https://edoc.coe.int/en/media/7495-information-disorder-toward-an-interdisciplinaryframework-for-research-and-policy-making.html

Wineburg, S., \& McGrew, S. (2017). Lateral reading: Reading less and learning more when evaluating digital information (SSRN Scholarly Paper No. ID 3048994). Retrieved from https://papers.ssrn.com/abstract $=3048994$ 